\title{
Trade between Kashmir and Central Asia via Traditional Corridors of Ladakh
}

\author{
Ab. Hamid Sheikh (Corresponding author) \\ Centre of Central Asian Studies (CCAS), University of Kashmir \\ 190006, Srinagar, India
}

Tel: 98-5876-2851_E-mail: abhamid502@gmail.com; mr.sheikhhakmid@rediffmail.com

Received: July 25, 2015 Accepted: August 9, 2015 Published: August 19, 2015

doi:10.5296/ijch.v2i2.8060 URL: http://dx.doi.org/10.5296/ijch.v2i2.8060

\begin{abstract}
Kashmir valley with great geo-strategic significance, was an economic hub, connecting Indian sub-continent with Central Asia and rest of the world, since ancient times. However, this exchanging center lost it relevance with the Partition of Indian sub-continent in 1947, 'Greater Jammu \& Kashmir' was divided into Azad Jammu Kashmir administered by Pakistan and Jammu and Kashmir Administered by India and the State moved from main to margin as all the routes were closed for trade and traffic including Zojila Pass. Indian Administer Kashmir (J\&K) became wholly and solely dependent on Jawahar Tunnel for import and export. The people of J\&K still remain behind curtain for number of days due to climatic hazards, communal and political tension, in the age of globalization, modernization and regional integration. The author attempted to put forth historical significance and arguments for reviving traditional corridors via Ladakh on sound basis rather than making revival of ancient trade outlets subservient to peace and drug mafia.
\end{abstract}

Keywords: Kashmir, Pass, Trade, Ladakh, Central Asia, Merchant community

\section{Zojila and Inter-linked Passes}

Kashmir served as an economic corridor between South and Central Asia, three principal highways were facilitating such connections, leading to Khorasan, India and Tibet. ${ }^{1}$ The Zojila $^{2}(11,300 \mathrm{ft}$.) Pass has been since ancient times an important throughfare, connecting

\footnotetext{
1 Elias, N. \& Denison Ross, E. (1986). Tarikh-i-Rashidi. Delhi: Renaisance Publising House. p. 432.

2 It is called Zoji-la by the Tibetans, and Zoji-bal by the Kashmiris. The terminal syllable, in the language of each respectively, signifies "hill pass," and the proper name is a corruption of Shivaji or Sheoji, one of the three great Hindu deities; Bellew, H. W. (1875). Kashmir and Kashghar: A Narrative of the Journey of the embassy to Kashghar in 1873-74. London: Trubner \& Co. p. 94.
} 
Kashmir with Ladakh and thence with Tibet, Turkistan and China, at its best, a rough bridle-track, dangerous for ponies at certain points, so it was encouraged to entrust ones valuable property to the surer-footed coolie. ${ }^{3}$ The movement on this Pass continued from June to November, ${ }^{4}$ though top of Zojila remained under snow till end of June. ${ }^{5}$ The Envoy of Atalik Ghazi ${ }^{6}$ crossed this pass in December with extreme difficulty, and lost eleven of the coolies of his convoy, perished in a snow-drift. ${ }^{7}$ The Zojila pass has been an ethnographic watershed between Kashmir and the territory of the Bhauttas, as the Tibetian inhabitants of the Indus region were uniformly designed in Kashmirian tests (modern Kś But ${ }^{\mathrm{a}}$ ). ${ }^{8}$ Although, the route was not more secure than others, however, it was the chief trade route ${ }^{9}$ between Kashmir and Central Asia, ${ }^{10}$ followed by the Central Asian invaders, ${ }^{11}$ and rulers of Kashmir. ${ }^{12}$ This Pass gave a unique commercial importance to the state, recognized by the government of India, ${ }^{13}$ as the Pass was traversed by the caravans (moving traders) for transportation of goods over Kashmir and onwards into Kargil, Leh and Central Asia. ${ }^{14}$ So long as the Pass remained open, scarce an hour passes without meeting some party, made their way across, and as each little caravan went by, it was amusing to speculate from dress and language cited distant countries and many encampments had taken advantage of the first open weather to move on from the direction of Leh, wintered after leaving Yarkand, Kashgar, and various other Central Asian markets. ${ }^{15}$ Lawrence believes that if Srinagar would have been linked with the railway all the trade with Ladakh and Yarkand was eminent via Kashmir, or at any rate through Gilgit. ${ }^{16}$

\footnotetext{
3 Knight, E.F. (1896). Where the Three Empires Meet. London: Longmans. p. 88.

4 The State organizes a system, where each village or group of villages on the main route had to provide a certain number of coolies or ponies for transport, known as Res and coolies as Respas. The sanctioned rate of payment was usually half an anna a mile for coolie and one anna for a pony: Norris, Dermot. (1989). Kashmir: the Switzerland of India. Srinagar: Gulshan Publishers. p. 83.

5 D. Frederic. (1996). the Jummoo and Kashmir Territories. New Delhi: Cosmos Publishers. p. 532; Bourbel, De. (1897). Routes in Jammu and Kashmir. Calcutta: Thaker, Spink \& co. p. 191.

${ }^{6}$ Yakub Beg, upon winning power in the region from the Gobi desert to the Tian Shan Mountains, was called "Atalik Ghazi" or "Defender of the faith,"

${ }^{7}$ Bellew, H. W. (1875). Kashmir and Kashghar: A Narrative of the Journey of the embassy to Kashghar in 1873-74. London: Trubner \& Co. p. 94.

8 Stein, M.A. (1900). Kalhana's Rajatarangini, Vol. I. Delhi: Motilal Banarsidas. Book i, 312-316 note.

9 Knight, E.F. (1896). Where the Three Empires Meet. London: Longmans. p. 95.

${ }^{10}$ Bourbel, De. (1897). Routes in Jammu and Kashmir. Calcutta: Thaker, Spink \& co. p. 191.

11 Dulcha in early $14^{\text {th }}$ century, and Mirza Haidar Dughlat in $15^{\text {th }}$ century: Stein, M.A. (1899). the Ancient Geography of Kashmir. Patna: Indological Book Corporation. p. 93; Elias, N. \& Denison Ross, E. (1986). Tarikh-i-Rashidi. Delhi: Renaisance Publising House. p. 423.

12 The Sikh and Dogra rulers of Kashmir crossed this range, which formed the old natural frontier, and in turn subdued all the countries to the north of it as far as the great watershed of the Karakoram and Hindu Kush mountains, effected the conquest of Ladakh between 1834 and 1842: Knight, E.F. (1896). Where the Three Empires Meet. London: Longmans. p. 103.

13 A Note on J\&K (Jammu, 1928). p. 2.

14 Lawrence, W. (1895). the Valley of Kashmir. London: Oxford University Press. p. 384.

15 Doughty, M. (1901). Afoot through the Kashmir valleys. London Sands \& company. p. 85.

16 Lawrence, W. (1895). the Valley of Kashmir. London: Oxford University Press. p. 384.
} 


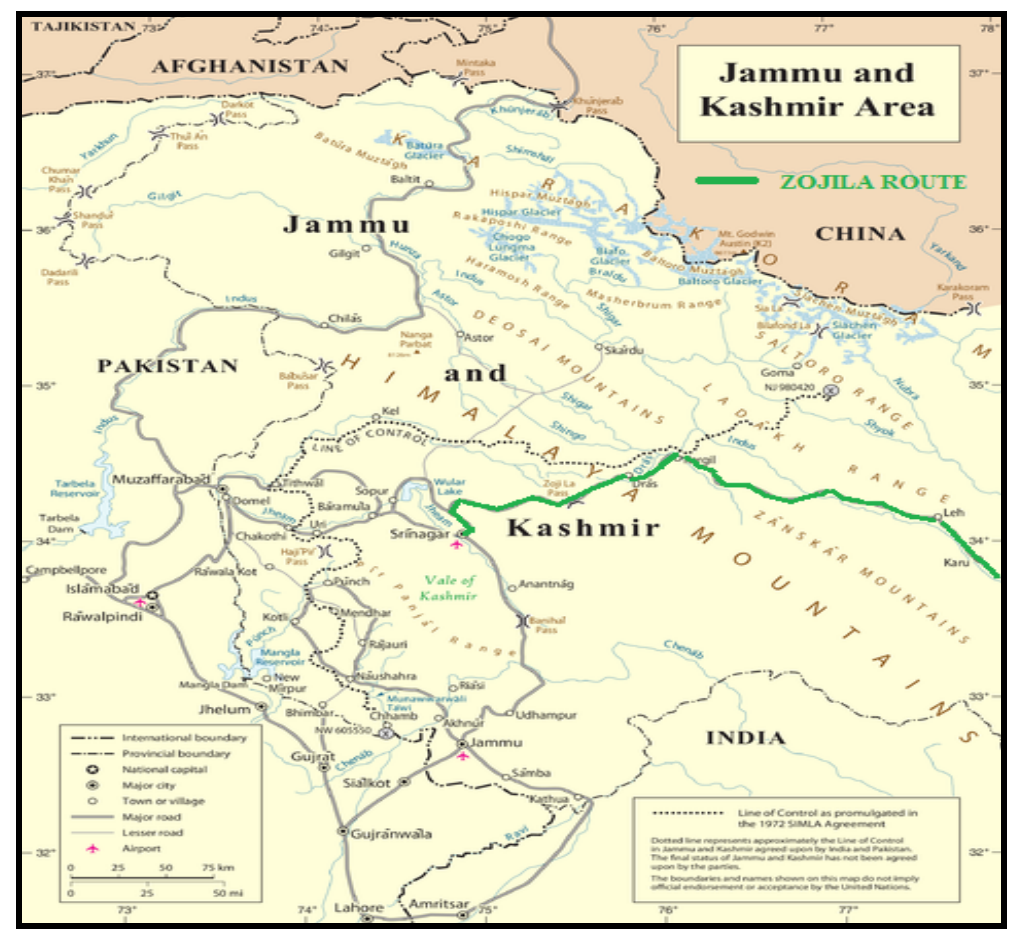

Map No. 3953 Rev. 3 United Nations

October 2005

Department of Peacekeeping Operations

Cartographic Section

Zojila route (Courtesy to Silk Road)

The passes of Ladakh ${ }^{17}$ have been categorized into three groups, used by traders depending on weather, type of goods and financial backing. The Tibetan Route or Leh-Demchak (Tibet) route, the main communication link between Leh and Tibet, connecting Leh with the Tibetan city of Lhasa, ${ }^{18}$ caravans from Lhasa moved to Kashmir with a number of horses laden with brick tea. ${ }^{19}$ The Tibetan king of Kashmir, Rinchana ${ }^{20}$ (1320-23 A.D) made his way to and back from Kashmir via this Route and served as a conduit for transmission of Buddhist ideology. ${ }^{21}$

\footnotetext{
17 Ladakh, 'the land of Passes' is a direct translation of the word Ladags, as la means 'pass' and dags means 'land'. The name is a derivation of several passes in the surrounding mountains connecting the region with Central and South Asia.

${ }^{18}$ Fewkes, J.H. (2009). Trade and Contemporary Society along the Silk Road. London: Routledge. pp. 21, $40-41$.

19 Knight, E.F. (1896). Where the Three Empires Meet. London: Longmans. 157.

${ }^{20}$ Rinchana travelled to Kashmir with aspirations to power, and through political maneuring was able to occupy the throne of Kashmir by the end of 1320 .

21 Jina, P. S. (1994). Tourism in Ladakh Himalaya. Delhi: Indus Publishing Co. p. 23.
} 


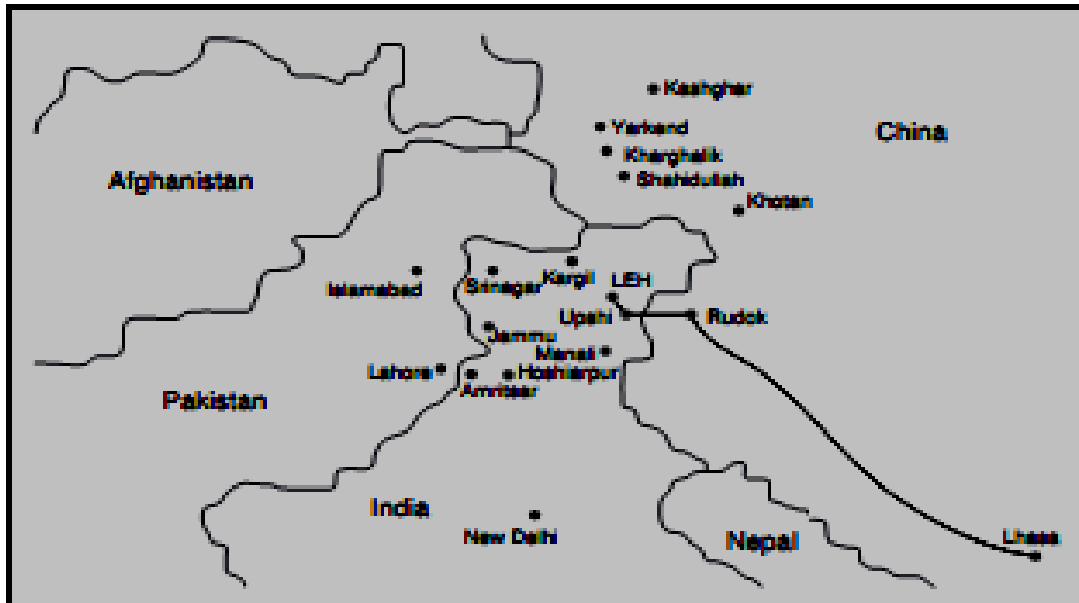

TIBETEAN ROUTE

The South Asian route connected Leh through a network of roads to key trading centers in Srinagar, Jammu, Lahore, Rawalpindi, Manali, and Amritsar, traders had choice depending on the city of destination. The Hoshiarpur served as a key market town on the way to Amritsar and the traders of Hoshiarpur participated in Ladakh's trading network. ${ }^{22}$

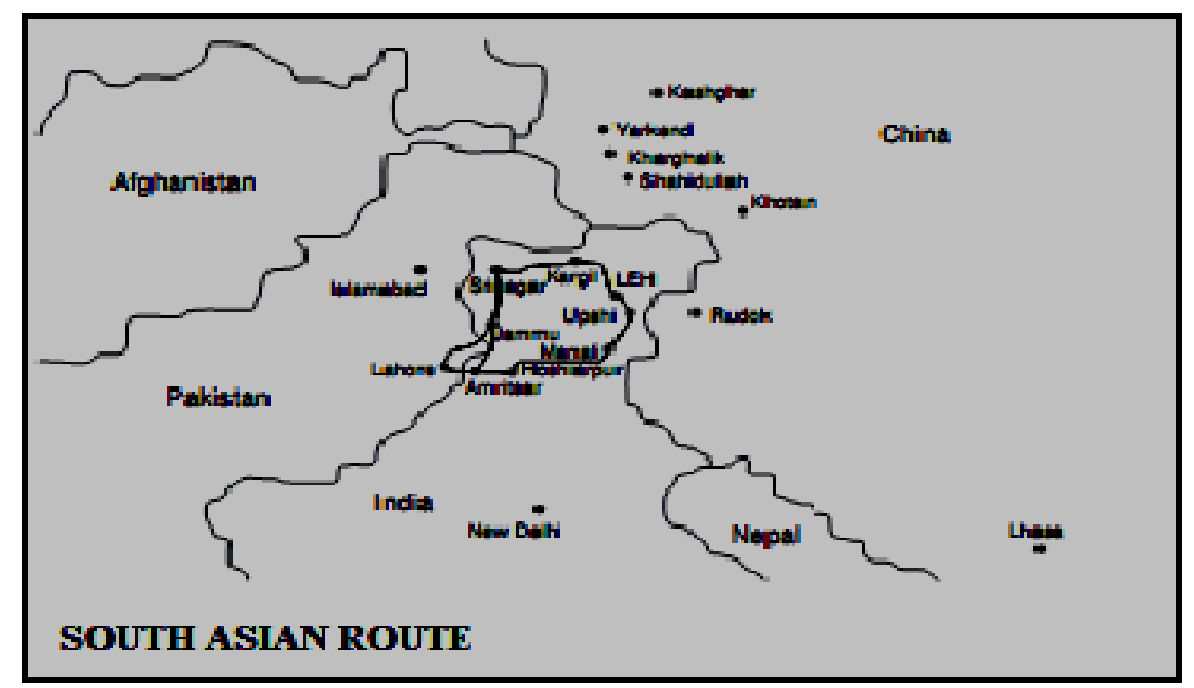

The Karakoram pass was the principal trade-route into Central Asia, ${ }^{23}$ regular means of communication between India and Turkestan, ${ }^{24}$ with trans-Karakorum routes linked Ladakh to Central Asia via the Karakorum pass leading to Yarkand, the Changchenmo route to Yarkand and Khotan and the Rudokh or Chang-thang route leading to Khotan. ${ }^{25}$ The Leh-Yarkand road was main communication link between the two regions, bifurcated at

\footnotetext{
${ }^{22}$ Fewkes, J.H. (2009). Trade and Contemporary Society along the Silk Road. London: Routledge. p. 42.

${ }^{23}$ Knight, E.F. (1896). Where the Three Empires Meet. London: Longmans. p. 174.

${ }^{24}$ Younghusband, F. (1924). Wonders of the Himalaya. London: John Murray. p. 53.

${ }^{25}$ Trotter, C. H. (1875). Mission to Yarkand and Kashghar in 1873-7. Calcutta: The Foreign Department Press. p. 10 .
} 
Ahgam $^{26}$, the Nubra valley route branched off from the Leh-Yarkand road. The caravans from Yarkand often halt a week at Panamik (a large and flourishing village a few miles below Changlung, Leh) to feed and rest the baggage animals after hard work and scant fare that they have had on the journey. ${ }^{27}$ This route was used in the hot weather, when, owing to the melting of the snow, the river (Shayok) ${ }^{28}$ was impassable. At the head of the Nubra valley a road passes over the main Karakorum chain by the Chorbut pass ${ }^{29}$ and descends into the Yarkand river at Khufelong. The summer route after crossing Shahidula ${ }^{30}$ opened via the Kilik, ${ }^{31}$ the Kilian, and the Sanju passes over the Kuenlun range to Kargalik and Yarkand. The Kilik Diwan (pass) was crossed in the March from Shahidula, and after going over another low pass the road joins the Kugiar route at Beshterek, south of Karghalik, little is known of this road, but grass and wood was available at every stage. ${ }^{32}$ Nearly three miles below, where the Togra-su enters the Karakash, the Kilian road leaves the Karakash valley and passes up an open ravine in a north-west direction. The road follows the stream from the pass till it debouches into the Turkestan plain at the village of Kilian, south of Bora on the road between Sanju and Karghalik. ${ }^{33}$ The third and most frequented road from Shahidula was via Sanju. It leaves the Karakash 20 miles below Shahidula at Mazar Abu Bakar, from which place the road ascends to the summit of the Sanju (also happily named "Grim") pass

\footnotetext{
26 A village belonging to Leh on the left bank of the Shayok river.

27 Trotter, C. H. (1875). Mission to Yarkand and Kashghar in 1873-7. Calcutta: The Foreign Department Press. p. 10 .
}

28 The Shyok was crossed in boats near Sati, where in the summer it was a very large and rapid river. Passengers and goods were carried over in boats, while the baggage animals were made to swim across.

29 It was formerly much used by the Baltistan merchants, but now rarely employed. It was probably not less than 19,000 feet high, and was always closed for at least nine months in the year, and was at no times practicable for laden animals. Janet Rizvi has argued that the difficult Ladakh route for trade with Central Asia was used more frequently in the $19^{\text {th }}$ century than the easier Baltistan route via the Mustagh Pass, which had been used in the $17^{\text {th }}$ and $18^{\text {th }}$ centuries, because there was no viable alternative, the Baltistan route was closed as Hunza and Chitral were politically unstable, and other routes had too many, sometimes unstable, glaciers. The road had been closed for several years previously by order of the Yarkand authorities owing to the risk to which travellers were exposed of being plundered and sold into slavery by the wild Kanjut robbers (of Hunza and Nagar), who coming down from their fastnesses to the north of Bunji and Gilgit used to render the whole valley of the Yarkand River from Kulunaldi up to Ak-tagh utterly unsafe for travellers or merchants unless in large parties and well armed: Trotter, C. H. (1875). Mission to Yarkand and Kashghar in 1873-7. Calcutta: The Foreign Department Press. p. 12; Rizvi, J. (1999). Trans-Himalayan Caravans. New Delhi: Oxford University Press, p. 34.

30 At Shahidula was a small fort which during the time of the disturbances in Eastern Turkestan (which resulted in the accession of the King) was occupied by a detachment of the Maharaja's troops from Kashmir. These were subsequently withdrawn and the place is now generally recognized as belonging to the Kashgbar ruler.

31 Traders were seldom or never allowed to use the former which was easiest and shortest, it follows the course of the Toghra, a considerable stream which enters the Karakash nine miles below Shahidula. The flood of this stream in hot weather often detain travellers a considerable time on its banks: Trotter, C. H. (1875). Mission to Yarkand and Kashghar in 1873-7. Calcutta: The Foreign Department Press. p. 13; Bourbel, De. (1897). Routes in Jammu and Kashmir. Calcutta: Thaker, Spink \& co. p. 339.

32 Trotter, C. H. (1875). Mission to Yarkand and Kashghar in 1873-7. Calcutta: The Foreign Department Press. p. 13; Bourbel, De. (1897). Routes in Jammu and Kashmir. Calcutta: Thaker, Spink \& co. p. 339.

33 This road was sometimes used in the summer as an alternative to that over the Sanju Pass, it was somewhat higher than the Sanju Pass, but, although impracticable for laden horses, was not so difficult to traverse. 
which, although not more than 16,700 feet above sea level, was decidedly the most difficult obstacle on the road to Yarkand. The road leads to Yarkand, meet the Kilian route at Bora, and the Kilik and Kugiar routes at Karghalik. ${ }^{34}$

The Changchenmo route from Leh to Turkestan crossed via the Kailas range and the range were crossed either by the Chang La (17,600 feet), or the Kay La (17,900 feet), by the former and easier road of the two it was 23 miles from Zingral to the large village of Tankse, ${ }^{35}$ situated on one of the tributaries of the Shayok River and by the Kay La foot passengers shorten the road by some six miles. The roads over both passes, although free from glaciers, were very difficult, although not absolutely necessary, to employ yaks in carrying goods across. The extreme eastern route, via the Chang-tang from Leh to Khotan might follow the route by the Pangong Lake, never has been used as a trade route on a large scale, because of the fear of the Tagh-lik. ${ }^{36}$

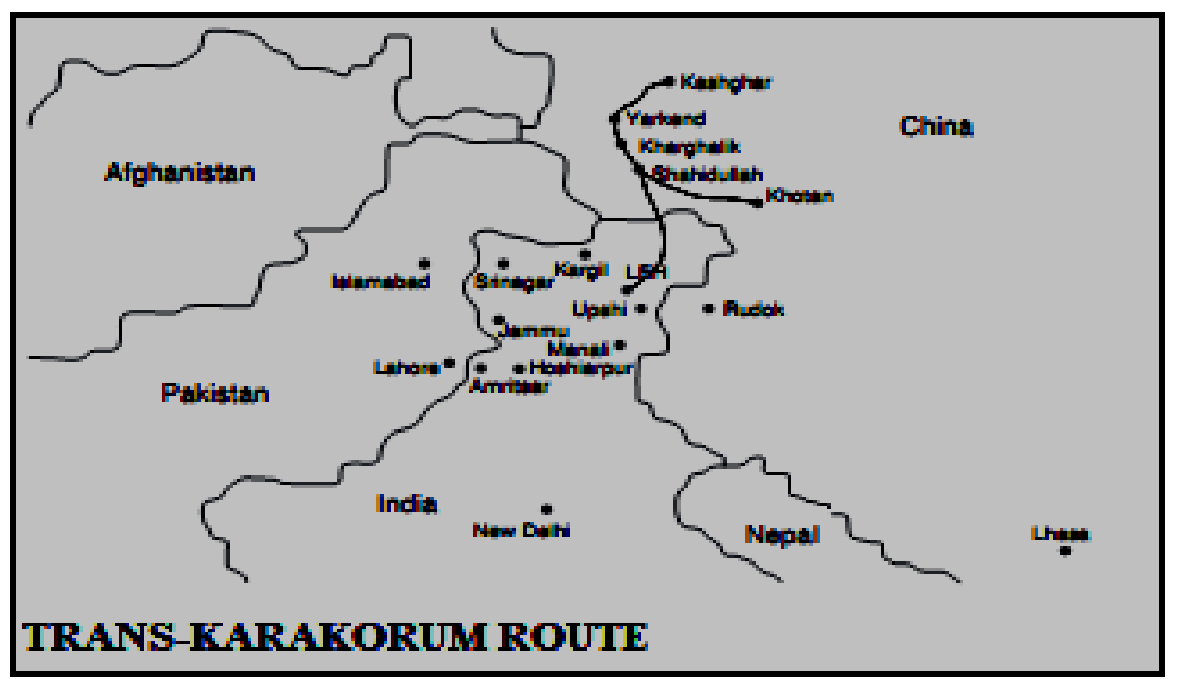

One of the important trans-Kashmir outlets through Zojila was Kargil-Iskardu-Gilgit link road. Kargil was/is equi-distant from Kashmir, Baltistan and Ladakh; hence, it was named as Kar-kil meaning equal distance, which later on transformed into Kargil, a contributory to the connecting links of Ladakh. ${ }^{37}$ Iskardu in Pakistan Administered Kashmir (PAK) and Gilgit was equally an important link between Kashmir and India on the one hand and Xinjiang China and Central Asia on the other. ${ }^{38}$ It was, as such, a bustling centre for trade and

${ }^{34}$ Trotter, C. H. (1875). Mission to Yarkand and Kashghar in 1873-7. Calcutta: The Foreign Department Press. p. 13.

${ }^{35}$ Tankse is the last place on this road where supplies are procurable, and was, by the shortest route, 350 miles from Sanju, the first large village encountered in Turkestan.

${ }^{36}$ Wandering tribes of Tartars, nominally subject to the Chinese officials at Gartokh and Rudokh, but practically only so far subject to them that they would abstain from committing violent aggression on parties travelling under the protection of those authorities: Trotter, C. H. (1875). Mission to Yarkand and Kashghar in 1873-7. Calcutta: The Foreign Department Press. p. 15.

${ }^{37}$ Rizvi, B.R. (1993). The Balti A Scheduled Tribe of Jammu and Kashmir. New Delhi: Gyan Publishing House. p. 11.

${ }^{38}$ Dani, A. H. (1991). History of Northern Areas of Pakistan. Islamabad: National Institute of Historical and Cultural Research. p. 214. 
commerce $^{39}$ besides a facilitator to the spread of Islam in Kashmir.

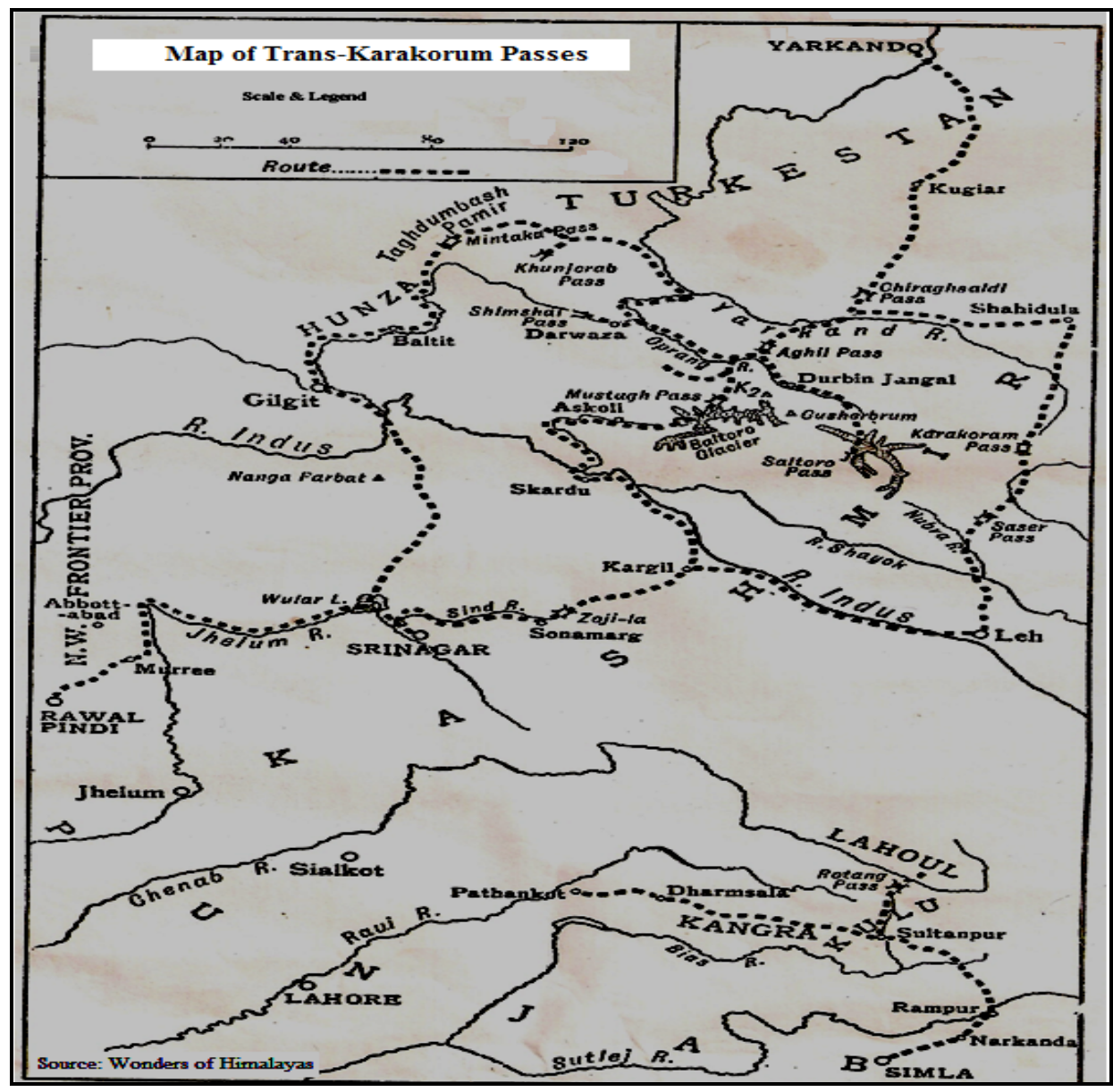

\section{Trade Organisation}

Kashmir maintained commercial and cultural relations with South and Central Asia through these links since ancient times, and served as a trading entrepot that connected multiple geographic areas. The substantial trans-surface connections with Central Asian and Chinese world, sequentially boosted her trade volume despite occasional periods of discomfort and decline. However, data about Kashmir and Central Asia trade volume is available from 1907-08 whence the quantum of imports from Central Asia was estimated at 1891 mounds ${ }^{40}$ of goods worth the value of Rs. 18071 for whole valley. The Samvat years between 1970 and 1977 were worthwhile of India-Central Asia trade as the volume of trade increased from Rs. $58,00,400$ to Rs. $93,05,931$. $^{41}$ However, the said trade registered a rapid decline from Samvat 1978, reached to Rs. 12,92,388 in Samvat 1994-95, due to transition in Russia in the aftermath of the $2^{\text {nd }}$ World War. Thereafter, the said trade picked up again as a result of

${ }^{39}$ Rizvi, B.R. (1993). The Balti A Scheduled Tribe of Jammu and Kashmir. New Delhi: Gyan Publishing House. p. 11.

${ }^{40}$ A unit of weight equal to $37 \mathrm{~kg} / 82 \mathrm{Ib}$.

${ }^{41}$ Trade Report of Jammu and Kashmir State, Samvat year 1992-95 (1935-38). Department of Industries and Commerce, Jammu, Ranbir Government Press. 1940. 
marked economic progress in Soviet Russia. In sequence, Russian industrial products flooded Indian markets though subsequently bilateral trade volume declined ${ }^{42}$ due to political disturbance in Chinese Turkestan, ${ }^{43}$ one of the trade corridors to Soviet Russia. However, such a fall was more visible in Indian exports rather than imports from Central Asia for the simple reason that Indian products failed to compete the Russian goods in Central Asia. It was also because of India's continued dependence on the supplies of charas and felts from Central Asia. ${ }^{44}$

In the trading networks of Central Asia the 'most vibrant of the trading stations' were towns between inhabited and uninhabited sections of routes, where traders rest and refuel before continuing onward, or the 'first sizeable settlement reached by caravans' after inhospitable terrain, such locations included the towns of Yarkand, Khotan, Kashgar, Gilgit, Leh ${ }^{45}$ and Srinagar. ${ }^{46}$ The important trading items imported into and exported from Kashmir were shawl-wool, charas (drug), silver, felts, tea, Russian leather, velvets, coarse silk, ${ }^{47}$ gold, turquoises, Khotanis carpets, coral, musk, tobacco, raisins and other dry fruits, ponies and salt, imported into Kashmir, while, the exports from Kashmir comprised cotton, chintze, silk, shawls, brocades, opium, heron-plumes, turmeric and other Indian species. ${ }^{48}$ The caravans (moving traders) carried with them a curious assortment of salt brick, tea, silver goods, exquisite silks and embroideries of great beauty of colour and design, printed Russian cottons, curious barbaric jewellery and polished pebble work from Turkestan and Ladakh. ${ }^{49}$ Eight hundred horse-loads, each load weighing 28 trak, ${ }^{50}$ of shawl-wool were brought to Kashmir annually, from Rooduk ${ }^{51}$ and Chayeenthan (residence of head Lama in Lhasa). The ruler of

\footnotetext{
42 Trade Report of the Jammu and Kashmir State, Samvat 1989-90. pp. 21-22.

43 Trade Report, 1992-95 (1935-38). p. 24.

44 Trade Report of the Jammu and Kashmir State, Samvat year 1989-90. pp. 21-22.
}

${ }^{45}$ Leh, conveniently situated as it was about half-way between the markets of India and those of Central Asia, had become the terminus for the caravans from both regions. In the summer, traders arrive at Leh from every part of India, and from Turkestan, Tibet, Siberia, and the remotest districts of Central Asia. Here the goods and produce of the south were exchanged for those of the north. It was seldom that a caravan from India goes north of Leh or that one from Central Asia proceeds south of it. The merchants, who were travelling for months along the difficult roads from either direction, meet here and dispose of their loads, to a great extent by barter, but before they commence the long, weary homeward journey, they rest here for a month or two, so that the bazaar and the environs of the city were thronged with the camels, yaks, and other beasts of burden, as well as with men from all corners of Asia: Knight, E.F. (1896). Where the Three Empires Meet. London: Longmans. p. 177; Younghusband, F. (1924). Wonders of the Himalaya. London: John Murray. p. 61.

46 Rizvi, B.R. (1993). The Balti A Scheduled Tribe of Jammu and Kashmir. New Delhi: Gyan Publishing House. p. 11-12.

47 The industry developed during the reign of Sultan Zain-ul-abdin (1420-70) and thrives till date with large remittances and job to tens, hundreds and thousands of natives. To quote Mirza Haider Doughlat, "among the wonders of Kashmir are the quantities of mulberry trees cultivated for their leaves from which silk is obtained": Elias, N. \& Denison Ross, E. (1986). Tarikh-i-Rashidi. Delhi: Renaisance Publising House. p. 434; Report on the administration of the Jammu and Kashmir State for the Samvat year 1973 (1916-17). p. 41,

48 Cunningham, A. (1977). Ladakh, Physical, Statistical and Historical. New Delhi: Sagar Publications. p. 291.

49 Doughty, M. (1901). Afoot through the Kashmir valleys. London Sands \& company. p. 85.

${ }^{50}$ Unit of measurement, One-sixteenth of a kharwar was designated as trak.

51 A town in the district of Leh. 
Kashmir was careful not to make any hostile demonstration against Tibet, ${ }^{52}$ for fear of the loss of revenue he would suffer from any disturbance of the trade in shawl-wool, ${ }^{53}$ cause the stoppage of the manufacture of shawls and deprive Valley of the yearly revenue of ten lakhs of rupees that it derives from this source. The famous Tibet-baqals ${ }^{54}$ exchanged their raw wool for manufactured Kashmiri shawls and sold them advantageously in various markets of Central Asia, China and Europe. Charas (derived from hemp), again a chief article of import from Central Asia, ${ }^{55}$ was estimated at 500 small maunds (7240 Kgs) worth Rs 24,000 annually. ${ }^{56}$ It was mostly imported from Yarkand by Hindu merchants of Hoshiarpur. It remained a staple trade article, although the hemp plant was endemic all over the Indian Himalayas including Kashmir. However, the imports from Yarkand were preferred as a drug. ${ }^{57}$ In 1983 (1925) 21 maunds and 15 seers of Yarkandi charas were purchased from a Central Asian traders at the Safa Kadal sarai Srinagar for Rs. 2,396,73. ${ }^{58}$

In $17^{\text {th }}$ century, the Mughal Emperor lent military aid to Ladakh in a war with the Tibetan empire and consequently signed the Treaty of Timisgong in 1684, conceded to Kashmiri traders the right to free access to the Chang-tang region of Ladakh for the trade of wool and pashmina. $^{59}$ It was during the period of Ranbir Singh that the British first stationed an officer in Leh town. The initial posting was in response to trade concerns, which of course played an important political role. For the development of trade, officer at Leh was instructed to see that no duties were levied in excess of those fixed in tariff, to inquire into the nature and extent of the trade between India and Central Asia, and to suggest measures for developing this trade. ${ }^{60}$ The British officer was a trade official and a political agent to ensure that the Maharaja did not have full control over the trade with Central Asia. The Treaty High Road, ${ }^{61}$ was kept

\footnotetext{
52 The Persian and Turkish name for Ladakh as the Tibet in Turkish signifies shawl-wool and is applied to the country for being main source of it.

53 The pashm (raw wool) was imported into Kashmir from Ladakh since ancient times for manufacturing of the most fabulous Kashmiri shawls and was quite lucrative to the state for its earnings were next to land revenue to the state: Arora, R.C. (1940). In the land of Kashmir, Ladakh and Gilgit. Jay Kay Book House. p. 154.

54 The merchants of Srinagar who dealt in pashm from Ladakh were also known as Tibet Baqals.

55 Report on the administration of the Jammu and Kashmir State for the Samvat year 1969 (1913-14). p. 52.

56 Cunningham, A. (1977). Ladakh, Physical, Statistical and Historical. New Delhi: Sagar Publications. p. 244.

57 Rizvi, B.R. (1993). The Balti A Scheduled Tribe of Jammu and Kashmir. New Delhi: Gyan Publishing House. pp. 189- 90 .

58 The administrative report of the Customs and Excise Department Jammu and Kashmir Government for the Samvat year 1983 (1926-27), 32.

59 Rizvi, B.R. (1993). The Balti A Scheduled Tribe of Jammu and Kashmir. New Delhi: Gyan Publishing House. pp. 53-55, 70 .

${ }^{60}$ Henderson, G. and Hume, A.O. (1981). Lahore to Yarkend. Incidents of the Route and Natural History of the Countries Traversed by the Expedition of 1870 Under T. D. Forsyth. Lahore: Sang-E-Meel Publications. p. 5.

${ }^{61}$ Since the commercial treaty that was entered into between the Governments of India and Kashmir in 1870, a representative, known as the British Joint-Commissioner, at Leh, centre of the trade with Eastern Turkestan, as well as with Tibet. His duty was to settle all disputes between Indian government subjects and natives of Kashmir on the one hand, and the Central Asian merchants, subjects of Russia and China on the other hand. The presence of this officer at so important a centre has produced excellent results, most of the abuses that hampered the trade on this route have been swept away, and the merchants were no longer so outrageously blackmailed as before on their way through Kashmir territory. The duties that were once levied on caravans passing through
} 
under the executive administration of a British Joint Commissioner, whose permission was to be obtained in order to travel on it, ${ }^{62}$ was the most popular route. ${ }^{63}$

Trade and commerce on various links was conducted on a large scale by a heterogeneous community of merchants from different regions and ethnic backgrounds, the Russians, British, Indian, Chinese (Manchus, Khitai, Tunganis ${ }^{64}$ ), Badakshanis, Afghans, Kashmiris, Kanjuts, Baltis, Khokhandis, Bukharans, Kazakhs, Mongols, Armenians, ${ }^{65}$ Iranians, Shirvanis, Tartars, Hindus and Central Asian Jews (of whom there was a large colony in Kokand). ${ }^{66}$ Nazaroff

Leh were abolished some years ago by the Maharajah's Council, but the officials of that city quietly ignored the order, charged the tolls, and pocketed them all for a year or so afterwards, before they were detected: Knight, E.F. (1896). Where the Three Empires Meet. London: Longmans. p. 159.

62 Nazarof, P.S. (2008). Moved on from Kashgar to Kashmir. Srinagar: Gulshan Books, p. 257.

${ }^{63}$ Before the 1860s the British in South Asia were disinterested in trade along the Central Asian routes through Ladakh, considering Chinese Central Asia a restricted market as the Russians had established trading privileges and a factory in Kashgar, and the journey was hazardous enough that profits were not assured. This changed in the early 1860s, when a general uprising of Muslim Tungans spread revolutionary action throughout Chinese Central Asia. Yakub Beg, a soldier of Kwodja Buzurg Khan, was sent to Kashgar by General Khudoyar Khan Alimkul of Tashkent "to help his co-religionists" and Yakub Beg, upon winning power in the region from the Gobi desert to the Tian Shan Mountains, was called "Atalik" or "Defender of the faith," and European powers took notice of this formation of a powerful new "Muhamadan State in Central Asia". Yet this was not a religious movement within the political realm, the supplanted Kwodja Buzurg Khan had also been Muslim. Instead, this struggle was for the establishment of a regional government independent of China. The abrupt power shift in Chinese Central Asia prompted British and Russian governments to scramble for alliances, sending ambassadors and establishing embassies with Yakub Beg's government. British interest was excited by Yakub Beg's refusal to recognize Chinese granted Russian trading rights in the region, which resulted in cessation of Russian trade with China. Through Ladakh, and the Trans-Karakorum route, the British government in South Asia attempted to formulate a trade agreement with Yakub Beg's government as part of a plan to create a buffer state with Russia. To this end they sent a trade mission with Douglas Forsythe through Leh in 1870. Yakub Beg's forces were not strong enough to keep Russian forces from re-entering Kashgar, and he was forced to sign a treaty with the Russians in 1872. Thus when the British Forsyth mission went to request similar trade rights from Yakub Beg's government in 1873, they were rebuffed. This flurry of political activity subsided, however, as the Chinese recaptured Sinkiang and regained control of this part of Central Asia in 1877. Yet this region continued to be of significant interest to the British in South Asia. Thus the Karakorum Pass had been declared a free highway for commercial trade under a treaty from 1870 between officials of British India and Jammu and Kashmir: Skrine C.P. and Nightingale, P. (1973). Macartney at Kashgar: New Light on British, Chinese and Russian Activities in Sinkiang, 1890-1918. London: Methuen, p. 10; Soucek, S. (2001). A History of Inner Asia, Cambridge: Cambridge University Press. p. 16.

${ }^{64}$ Staunch Muslims as they were, Tunganis spoke the Chinese language and had scanty hair and resembled Mongols for they were actually the offshoots of the Tartars, (those Central Asians who came from East Central Asia and founded an empire stretching into Serbia, Russia, and Ukraine) and Chinese women. They made up the largest part of the immigrant Muslim population from Kansu, Chen-his and Szechwan and professed Sunni faith (some of their Jurists belong to the Hanfi School of Law and others to the Shafiite school of Law). They had great influence of Naqash Bandiya (Sufi order), offered prayers in Arabic language, abstained from pork, wine and Tobacco and shaved their moustaches and used the Chinese language for sermons and commentaries. Their commercial talent and their culturally intermediate position between China and the Muslim world enabled them to play a powerful role in trade. Since many of them could speak a little Tartary, they also had an advantage in the trade with the Kazakhs, and the people of Ili and Tarbagatai regions: The Cambridge History of China. Vol. X. 66-68

${ }^{65}$ Bellew, H. W. (1875). Kashmir and Kashghar: A Narrative of the Journey of the embassy to Kashghar in 1873-74. London: Trubner \& Co. pp. 386-387.

${ }^{66}$ Cambridge history of China. Vol. X. p. 83. 
reports about the ethnic composition of traders at Ladakh, "here you may meet Tibetans from Lhasa, which is three months journey from here, Kashmiri often dressed in a most picturesque and dandified fashion, Hindus from Peshawar, stalwart mountaineers from Baltistan, whose grey costume blends so closely with the rocks that when they were resting by the roadside, tired of the heavy load, they can hardly be distinguished from the ground, clumsy Kashgar sorts with their long halats, and others." ${ }^{, 67}$ Besides, there were the Yarkandis, Argons, ${ }^{68}$ Hindus from Kullu and Hoshiarpur. ${ }^{69}$ The natives of Yarkand, Turkestan, and Iskardo, as well as those of the country itself, all in their peculiar and distinctive costumes, were in bazaars daily. ${ }^{70}$ The Kashmiri traders had their diaspora in Yarkand, Kashghar, Khotan and Lhasa. Cunningham writes in 1856, "Moorcroft was informed that the population of Yarkand was between fifty and sixty thousand, a number which would require about 10,000 houses, $\ldots$ of these I was told that 500 houses belonged to Kashmiris alone..." He adds, "There are some hybrids (Arguns) between the Kashmiris and the native races found in Kashghar, Yarkand, Aksa and Khotan.,"71

The merchant community that conducted trade between India and Central Asia across Kashmir, was broadly fragmented into two groups, the 'Andijanese" ${ }^{, 72}$ or 'Kashmiris'. The Andijanese were those who traded at Kashgar, which in first quarter of the $19^{\text {th }}$ century, was a bigger city than Bukhara, and the Kashmiris were those who traded at Yarkand. ${ }^{73}$ The Andijanese also operated at Kokand, Tashkent and Bukhara though their role was considerably smaller at Tibet, Ladakh, Baltistan, Afghanistan and the Pamir countries where Badakshanis, Afghans, Baltis, Tibetans and Hindus, if not Jews or Russian Tartars, were certainly predominant. ${ }^{74}$ The Kokandis, Bukharans, Badakshanis and Kashmiris had trade cooperation with the $\mathrm{Begs}^{75}$ (local chiefs) in Atishahr region. Since Kashmir bordered closely with Central Asia, its capital city, Srinagar, was the hub of trading activity for the Turkish, Tibetan, Ladakhi, Balti, Indian and Kashmiri merchants. These traders had rest houses as well as religious Shrines in Kashmir. ${ }^{76}$ The Immigrant British, Kokandi, Russian and the Chinese

\footnotetext{
67 Nazarof, P.S. (2008). Moved on from Kashgar to Kashmir. Srinagar: Gulshan Books, p. 278.

68 They were the descendant of Muslim traders of Yarkand and Kashgar and the local Ladakhi women with whom the former married and lived, during prolonged winters when the Karakoram pass would remain closed due to heavy snowfall. Mutah qualifies a man to marry with a lady of his choice for a stipulated period of time which varied between few hours to 100 years. The practice of Mutah obtained in Arabia as a process of ecological adaptation. The arid or semi-arid situation that existed in Arabia also existed in Kargil. Drew believes that the Arghaun race developed due to the intermarriage of Kashmiri merchants with women of Ladakh: Frederic Drew, 244.

69 Arora, R.C. (1940). In the land of Kashmir, Ladakh and Gilgit. Jay Kay Book House. p. 154.

70 Murray Aynsley, J. C. (1879). Hindostan, Kashmir, and Ladakh. London: H. Allen \& CO. p. 97.

71 Cunningham, A. (1977). Ladakh, Physical, Statistical and Historical. New Delhi: Sagar Publications. p. 291.

72 Andijan being the name of a city and of a region in the Farghana Valley area under Kokand's control.

73 Cambridge History of China. Vol. X. p. 83.

${ }^{74}$ Wathen, W.H. (1835). Memoir on Chinese Tartary and Khotan. Journal of the Asiatic Society of Bengal 4 (48). 654: Cambridge History of China. Vol. X. 83.

75 Cambridge History of China. Vol. X. 86.

76 Hassan, M. (1959). Kashmir under the Sultans. Srinagar: Ali Mohammad and Sons. p. 247.
} 
merchants operated from Kashgar, ${ }^{77}$ the Afghans operated from Yarkand, ${ }^{78}$ Kashmiris $^{79}$ and Chitralis also from Yarkand and Hindustanis from Khotan, did so either independently or through partnership with a group of merchants. ${ }^{80}$ The community of Kashmiri merchants, described as a far-flung trading race, comparable to European Jews or Armenians, whose agents were found all over South and Central Asia, ${ }^{81}$ brought pashm (raw wool) to Srinagar, though a few Chinese and Tibetan traders termed Bakals were also involved in the said trade. ${ }^{82}$ They disposed of the pashm (raw wool) to the pashm farosh (wool retailer) of Kashmir Valley. ${ }^{83}$ The ruling class, to a certain extent had a share in trade structure. The governor of Khotan traded in saffron, Kiryana, Kemkhabb and white silk. ${ }^{84}$

The State government revised its taxation policy from time to time, in order to boost the trade from Kashmir, as a considerable income was generated from customs and octroi levied on the import-export trade, collected from custom post of Zojila pass, and Ganderbal. It (Ganderbal) was an important station for the collection of duties levied on merchandize imported from, or exported to, Tibet and Yarkand. The duty on each shawl was rupees 3 but on shawl-wool 4 rupees per trak was charged. The state offered protection and encouraged local traders to go for export trade, and provided them tax exemption on exports. In 1891-92, the Kashmir Darbar (the title usually applied to the govt. of a native state) provided incentives to the Kaliwal Indus valley men for trade between Kashmir and the Punjab. In 1885, Maharaja Ranbir Singh (1829-1885 A.D) of Kashmir, through a parwana (farman) exempted the traders from payment of octroi duties in Gilgit, though the unscrupulous officials unlawfully realized the same and forced the traders to sell their goods at lower prices than fixed by the Dogras. The merchants were evenly charged Rs 1.8.0 on each load of Indian or Kashmir merchandise at Gilgit. This was besides Rs 1.8.0 and Rs 1.0.0 charged per-load of exports in Yasin, Chitral, Hunza and Nagar respectively. ${ }^{85}$

The State patronage was visible in the construction of countless rest houses or sarais $^{86}$ in the

77 Bellew, H. W. (1875). Kashmir and Kashghar: A Narrative of the Journey of the embassy to Kashghar in 1873-74. London: Trubner \& Co. pp. 386- 87.

78 Taylor, B. (1997). Travels in Cashmere, Little Tibet and Central Asia (1876-81). New Delhi: Asian Educational Service. p. 10.

${ }^{79}$ Every trader who came from Ladakh was reckoned as a Kashmiri and was put under a Kashmiri Arkal or consul: Bayard Taylor, 216.

${ }^{80}$ Taylor, B. (1997). Travels in Cashmere, Little Tibet and Central Asia (1876-81). New Delhi: Asian Educational Service. pp. 216-217.

${ }^{81}$ Bamzai, P.N.K. (1994). Political and Cultural History of Kashmir. New Delhi: Light and Life Publishers. p. 507.

${ }^{82}$ The merchants of Srinagar who dealt in Pashm from Ladakh were also known as Tibet Baqals.

${ }^{83}$ Rizvi, J. (1999). Trans-Himalayan Caravans. New Delhi: Oxford University Press, pp. 57-58.

${ }^{84}$ File no. 332, Samvat 1923 (1866-67), His Highness government of Jammu and Kashmir, Persian/General records, Jammu Archives

${ }^{85}$ Kemon, Captain R.L. Assistant to the Resident for Leh, Ladakh to Resident in Kashmir. No. 509, November 8, 1899. GOI, FGN, Front-A, February 1900. No's 17-18 (A.S.P. 286).

${ }^{86}$ The sarai, an inn and storage place for goods was the economic and social center of traders in North Indian and Central Asian trading towns. Sarais were not simply hotels, but functioned as trading areas, transport centers and taxing posts. They exist for the use of coolies, ponies, etc: Collett, J. (1898). A Guide for Visitors to 
far off and nearby villages, towns and cities for the comfort and stay of general and caravan traders. The sarais characterized an inn-cum-warehouse, with rooms on the upper storey for accommodation of the merchants and storerooms in the ground floor besides pasturage for the horses. ${ }^{87}$ The sarais had also a vast courtyard for loading and unloading merchandise. Besides having a sufficient space for a large number of beasts of burden, they were quartered by mosques and wells as deep as 100 feet. $^{88}$ Food was kept in excess to withstand urgency and for the convenience of the Central Asian traders, Kashmir government built two sarais ${ }^{89}$ in Srinagar. Besides sarais, there were also dak bungalows, ${ }^{90}$ a rest house of primitive construction, but nonetheless of welcome shelter. On special occasions abundant supply of all sorts of provisions were provided. ${ }^{91}$ E.F. Knight believes that dak bungalow was a hobby of the Dogra Maharaja, Pratab Singh. ${ }^{92}$ A book was provided at each rest-house, in which all persons were requested to enter their names, date of arrival and departure, and the fee paid by them in accordance with rule. If any cause of complaint arises, it was referred to the State Engineer, Jammu and Kashmir State. ${ }^{93}$

\section{Conclusion}

Kashmir enjoyed special status in the Indian subcontinent as it offered a direct land access of India to Turkestan, Yarkand, Khotan, and facilitated the free movement of diverse goods, merchants, explorers, spies and soldiers across different routes criss-crossing Kashmir. However, the Partition of Indian sub-continent in 1947, emergence of India and Pakistan on its debris, and the sequential wars between them in 1960's, 1970's and 1990's on Jammu \& Kashmir led to the emergence of artificial borders and obviously the closure of traditional trans-Ladakh and trans-Gilgit land routes. With that, process of free trade and traffic across hitherto 'Greater Kashmir' or Jammu \& Kashmir (J\&K) and Pakistan Administered Kashmir (PAK) freezed. Importantly, families and communities of the common ethno-historical lot fragmented with no intimate connection in between due to Line of Control (LoC) and the

Kashmir. Calcutta: W. Newman \& Co. p. 204.

87 Rizvi, J. (1999). Trans-Himalayan Caravans. New Delhi: Oxford University Press, pp. 227-29.

88 Taylor, B. (1997). Travels in Cashmere, Little Tibet and Central Asia (1876-81). New Delhi: Asian Educational Service. p. 189.

${ }^{89}$ Kak sarai and Safa Kadal sarai were halting points for some of the caravans from Kargil, Leh as well as Yarkand. Beyond the seventh bridge in Srinagar, is the Yarkand serai, filled with the Tartar-featured Yarkandis from Central Asia, fully as dark as from many months exposure to the sun and snow: Younghusband, F. (1911). Kashmir. London: Adam and Charles Black. p. 66.

90 Dak Bungalow was a purely Indian institution, at every convenient stage on a road a house was built by the government for the accommodation of travellers, furnished with chairs, tables and traveller can put up there for night, cook his meal, for which he was to pay a small charge, viz 8 annas for using the bungalow for three hours or less, and 1 rupee for 24 hours. Some few things can be obtained at fixed rates from the native, incharge. Food was exceedingly cheap, a fowl was 6 to 8 annas; a sheep was 4 to 6 rupees. One rupee a head a day gives a man everything he may desire in the form of food: Eckenstein, O. (1918). the Karakoram and Kashmir. Srinagar: Gulshan Books. pp. 7-8.

91 Bellew, H. W. (1875). Kashmir and Kashghar: A Narrative of the Journey of the embassy to Kashghar in 1873-74. London: Trubner \& Co. p. 40.

92 Knight, E.F. (1896). Where the Three Empires Meet. London: Longmans. p. 11.

93 Collett, J. (1898). A Guide for Visitors to Kashmir. Calcutta: W. Newman \& Co. pp. 204-05. 
rigid stand of the two nations on J\&K. While it is difficult to ascertain the exact number of divided families, every $5^{\text {th }}$ resident among the people of Greater Ladakh nevertheless claim to have his relatives and property on the other side of the LoC. Massive and intermittent displacement led to migration of many people from Kargil in J\&K to Pakistan or its Northern Areas of Gilgit. Currently, PAK has 19 refugee camps and about 24,574 displaced persons from Kashmir excluding those 10,000 people who live with their relatives. Displacement of the household affected their entire social and economic framework. Many lost their kith and kin and material assets and properties on one or the other side of the LoC. Many respondents from Kargil reported that several Balti families left behind landed property in Kargil and their revenue documents are still preserved in the Mahafiz Khana of Iskardu. These unhealthy developments triggered Kashmir conflict with immense human loss and damage of precious infrastructure. Alone due to militancy as a sequel of Kashmir conflict, more than one lakh people lost their lives in J\&K. Tens and thousands became maimed, marginalized, distitutes and orphans. Ailed were innumerable and alone in 2003-06, there were around 45,000 psychiatric patients. Damage to infrastructure has been inestimable. Economic growth of the J\&K was also a big causality, and during two decades of militancy (1980-2000), the Net State Domestic Product was only $12.45 \%$, far less than other Indian states.

\section{Copyright Disclaimer}

Copyright for this article is retained by the author(s), with first publication rights granted to the journal.

This is an open-access article distributed under the terms and conditions of the Creative Commons Attribution license (http://creativecommons.org/licenses/by/3.0/). 